non-transformed cells. Qualitative differences exist, however, in the polysomal sequences of these two types of cell.

We thank Drs G. A. Galau, R. J. Britten, and E. H. Davidson for informing us of their methodology and results before publication. This work was supported in part by a grant from the National Cancer Institute.

Division of Laboratories and Research,

New York State Department of Health, Albany, New York 12201

Received November 4, 1974; revised January 24, 1975

1 Grady, L. J., and Campbell, W. P., Nature new Biol., 243, 195-198 (1973).

2 Perry, R. P., and Kelley, D. E., J. molec. Biol., 35, 37-59 (1968).

3 Penman, S., Vesco, C., and Penman, M., J, molec. Biol., 34, 49-69 (1968)

Goldberg, R. B., Galau, G. A., Britten, R. J., and Davidson, E. H., Proc natn. Acad. Sci, U.S.A., 70, 3516-3520 (1973).

5 Galau, G. A., Britten, R. J., and Davidson, E. H., Cell, 2, 9-20 (1974).

Bishop, J. O., Morton, J. G., Rosbash, M., and Richardson, M., Nature, 250 199-204 (1974).

7 Wettstein, F. O., Staehelin, T., and Noll, H., Nature, 197, 430-435 (1963).

Perry, R. P., LaTorre, J., Kelley, D. E., and Greenberg, J. R., Biochim. biophys. Acta, 262, 220-226 (1972).

\section{Different susceptibility of DNA and RNA to cleavage by metal ions}

METAL ions are required in virtually every phase of genetic information transfer, and they are generally essential components of biochemical processes involving DNA and RNA. Under certain conditions, however, metal ions can have deleterious effects, and one of these, the degradation of polyribonucleotides, is not frequently considered by those who deal with nucleic acids in the presence of metals. No such degradation has been demonstrated with DNA, although it is known ${ }^{1}$ that DNA, like RNA, is subject to thermal degradation, and therefore can be expected to undergo some degradation also in the presence of metal ions. It is important to understand the relative susceptibility of polydeoxynucleotides and polyribonucleotides to degradation by metal ions to answer the following questions. To what extent is DNA, compared with RNA, vulnerable to metal ion degradation during biochemical experiments? What are the implications for metal ion toxicology? Is the difference in susceptibility to metal hydrolysis sufficient to make possible a quantitative separation of degraded RNA from undegraded DNA in a DNARNA mixture? Finally, does this difference in susceptibility reflect differences in the intrinsic stabilities of DNA and RNA, and perhaps throw light on the reason for the evolutionary selection of DNA, rather than RNA, as the favoured. bearer of the primary genetic information? These questions can be answered by a comparison of DNA and polyribonucleotide degradation by metal ions using a method of detection sensitive enough to respond to the first break in the macromolecule.

Polyribonucleotides are readily degraded by heating in the presence of various metal ions ${ }^{2,3}$. Zinc(II) ion ${ }^{3}$ is a very effective degrading agent, and the characteristics and mechanism of the zinc reaction have been thoroughly investigated ${ }^{3-5}$. The zinc degradation of poly(rA) is typical of that of polyribonucleotides $^{2}$. For these reasons we have chosen to compare the degradation, in the presence and absence of zinc(II) ion, of poly(rA) with that of calf thymus DNA. The non-degradability of DNA by metal ions has been suspected ${ }^{2,6,7}$ on the basis of assays which could, however, detect only very extensive cleavage. By following the zinc cleavage reaction by sedimentation velocity measurements, in conditions of strand separation, we can detect even one break per strand. The reactions were carried out at $p \mathrm{H} \mathrm{7.0,} \mathrm{low} \mathrm{ionic} \mathrm{strength,} \mathrm{with} \mathrm{and} \mathrm{without} 2 \mathrm{Zn}$ per nucleotide residue, and, for comparison of single and double stranded DNA, at each of two temperatures: $50^{\circ} \mathrm{C}$, which is below the melting range of the DNA under these conditions, and $80^{\circ} \mathrm{C}$, which is above it? (Poly(rA) is single stranded at both temperatures ${ }^{8,9}$.)

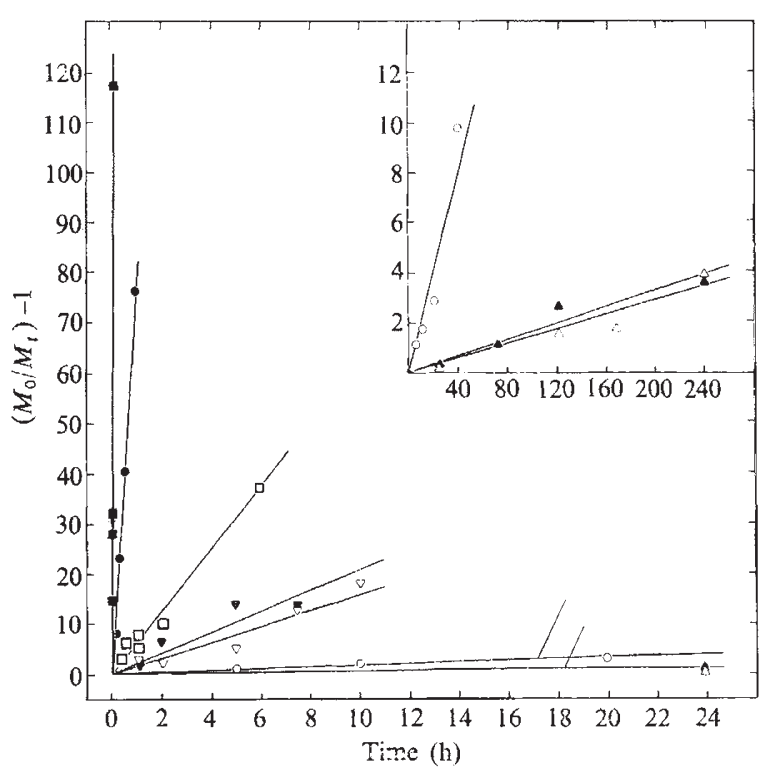

Fig. 1 Time course of cleavage of calf thymus DNA and poly(rA) at $50^{\circ} \mathrm{C}$ and $80^{\circ} \mathrm{C}, p \mathrm{H} 7$, with and without $2 \mathrm{Zn}$ per nucleotide residue, as measured by reduction of the weight average, single-strand molecular weight during times $t$ from the initial value $M_{0}$ to values $M_{t}$. DNA: $50^{\circ} \mathrm{C}$, (A) with $\mathrm{Zn}$, $(\triangle)$ without; $80^{\circ} \mathrm{C}$, ( $\left.\nabla\right)$ with $\mathrm{Zn},(\nabla)$ without. Poly(rA): $50^{\circ} \mathrm{C}$, (○) with $\mathrm{Zn}$, (O) without; $80^{\circ} \mathrm{C}$, ( $(\mathrm{O})$ with $\mathrm{Zn}$, ( $\square$ ) without. Calf thymus DNA $\left(M_{0}=1.2 \times 10^{6}\right)$ was from Worthington Biochemicals; the stock solution was prepared as before ${ }^{11}$. $\operatorname{Poly}(\mathrm{rA})\left(M_{0}=0.41 \times 10^{6}\right)$ was from Miles Laboratories. Reaction mixtures contained $0.10 \mathrm{mM}$ nucleotide residue and $5 \mathrm{mM} \mathrm{NaNO}_{3}$, and zinc ion was introduced as $\mathrm{Zn}\left(\mathrm{NO}_{3}\right)_{2}$; $p \mathrm{H}$ was initially adjusted to 7.0 by addition of $\mathrm{NaOH}$. For sedimentation measurements, zinc was removed from DNA solutions by batch exchange on Dowex-50(Na), and then to separate the strands ${ }^{12} \mathrm{NaOH}$ was added to $0.1 \mathrm{M}$ and $\mathrm{NaCl}$ to $1 \mathrm{M}$; poly(rA) solutions were made $0.01 \mathrm{M}$ in sodium EDTA buffer, $p \mathrm{H} 7.0$ and $0.1 \mathrm{M}$ in $\mathrm{NaCl}^{3}$ (poly(rA) remains single stranded under such conditions $\left.{ }^{8,9}\right)$. Weight average sedimentation coefficients were determined at $20^{\circ} \mathrm{C}$ (Beckman Model E ultracentrifuge, ultraviolet absorption optics) from the movement of the half-maximal position of the integral boundary pattern. Weight average molecular weights were calculated: for DNA, using the correlation of Studier ${ }^{12}$ for the alkaline medium, $\mathrm{S}_{20, w}=0.0528\left(M^{0.40}\right)$; for poly(rA), from the correlation of Fresco and Doty ${ }^{13}$ for neutral $0.15 \mathrm{M} \mathrm{NaCl}$,

$$
\mathrm{S}_{20, \mathrm{w}}=0.024\left(M^{0.45}\right)(\mathrm{S} \text { in Svedbergs). }
$$

The sedimentation results, in terms of the calculated weight average, single-strand molecular weights, are presented in Fig. 1. It is immediately obvious from Fig. 1 that a large difference in susceptibility to zinc cleavage exists between single or double stranded DNA, and poly(rA), so that very extensive zinc depolymerisation of poly(rA) occurs during a time in which DNA sustains negligible damage. Some cleavage of the DNAboth with and without zinc-was eventually detected, even at the lower temperature (inset of Fig. 1), but the effect of zinc on DNA cleavage was insignificant, both at 50 and $80^{\circ} \mathrm{C}$, compared with its effect on the cleavage of poly(rA).

All the plots of Fig. 1 fit straight lines reasonably well. Table 1 provides quantitative comparisons of the slopes of these plots, which represent rates of depolymerisation on a single strand basis. The Table also lists times required for reduction of the molecular weight to given fractions of the initial value. Table 1 shows that there was no significant added effect of zinc on the cleavage of DNA, either above or below the melting temperature, while there was a 200-300-fold increase in the rate of depolymerisation in the case of poly(rA). The rate for poly(rA) was 4,000 times greater than the rate for DNA, in the presence of zinc, when the DNA was double stranded (at $50^{\circ} \mathrm{C}$ ). When the DNA was single stranded (at $80^{\circ} \mathrm{C}$ ), poly(rA) was still degraded 1,000 times more rapidly than DNA. In the absence of zinc the degradation of poly(rA) was only 14 times faster at $50^{\circ} \mathrm{C}$ and four times faster at $80^{\circ} \mathrm{C}$. These results indicate that cleavage induced directly by metal 
Table 1 Rate of reduction of the weight average, single-strand molecular weight of calf thymus DNA, and of poly(rA), at $50^{\circ} \mathrm{C}$ and $80^{\circ} \mathrm{C}, p \mathrm{H} \mathrm{7.0,}$, with and without $2 \mathrm{Zn}$ per nucleotide residue

\begin{tabular}{|c|c|c|c|c|c|c|}
\hline \multirow[b]{3}{*}{$\begin{array}{l}\text { DNA } \\
50^{\circ} \mathrm{C} \\
80^{\circ} \mathrm{C} \\
\text { Poly }\end{array}$} & \multicolumn{2}{|c|}{$\begin{array}{c}\text { Slope }\left(\mathrm{h}^{-1}\right) \text { of } M_{0} / M_{\mathrm{r}} \\
\text { against } \mathrm{t}^{*}\end{array}$} & \multicolumn{4}{|c|}{$\begin{array}{l}\text { Approximate time (h) for } \\
\text { reduction of } M_{0}^{+}\end{array}$} \\
\hline & +7 & $-\mathrm{Zn}$ & to $1 /$ & & $\begin{array}{l}\text { to } 1 / 1 \\
+\mathrm{Zn}\end{array}$ & $0 M_{0}$ \\
\hline & $\begin{array}{l}0.016 \pm 0.002 \\
2.1 \pm 0.6 \\
\text { A) }\end{array}$ & $\begin{array}{r}0.014 \pm 0 . \\
1.6 \pm 0\end{array}$ & $\begin{array}{c}62 \\
048\end{array}$ & $\begin{array}{c}71 \\
0.62\end{array}$ & $\begin{array}{l}560 \\
4.3\end{array}$ & $\begin{array}{l}640 \\
5.6\end{array}$ \\
\hline $\begin{array}{l}50^{\circ} \mathrm{C} \\
80^{\circ} \mathrm{C}\end{array}$ & $\begin{array}{c}72 \pm 4 \\
1,400 \pm 400\end{array}$ & $\begin{array}{l}0.20 \pm 0.04 \\
6.2 \pm 0.6\end{array}$ & 0.00064 & $\begin{array}{l}5.0 \\
0.16\end{array}$ & $\begin{array}{l}0.12 \\
0.0062\end{array}$ & $\begin{array}{r}45 \\
1.4\end{array}$ \\
\hline
\end{tabular}

* Evaluated from the plots of Fig. 1 (the mean deviation for fit to the experimental points are appended). $M_{0}$, initial weight average molecular weight; $M_{t}$, values at times $t$.

$\dagger$ Calculated from the slope of $M_{0} / M_{t}$ against $t ; M_{0} / M_{t}=$ $1+$ (slope)t

ions is generally unlikely during in vitro manipulations of DNA, although it must be taken into account with polyribonucleotides. Figure 1 and Table 1 can serve as a guide to the amount of damage to be expected under various conditions.

The great difference in the susceptibility of polyribonucleotides, compared with polydeoxynucleotides, to zinc cleavage makes possible the quantitative removal of RNA from a DNA-RNA mixture. This becomes evident when one calculates from the data of Table 1 that, at $50^{\circ} \mathrm{C}$ with zinc, about 5,000 breaks occur in a poly(rA) strand for one break in a DNA strand. Selective zinc degradation of RNA has already been utilised ${ }^{10}$ in connection with chromatin reconstitution studies; our results indicate that the DNA components remain intact during such degradation.

Our results suggest also that DNA should be much less susceptible than RNA to deleterious action by metal ions in vivo. Thus the question arises whether these effects may be part of the reason for the predominant evolutionary selection of DNA, instead of RNA, as the bearer of the primary genetic information.

Obviously, any attempt to answer this question, as any question involving evolutionary hypotheses, must be speculative. It has been suggested ${ }^{1}$ that the relatively small difference in thermal stability of DNA and RNA can account for the choice of the DNA duplex as the repository of genetic information. But this difference in thermal stability is only about one threehundredth the difference in stability to metal ions. Moreover, metal ion degradation of polyribonucleotides proceeds ${ }^{5}$ through a mechanism that involves the $2^{\prime} \mathrm{OH}$ group, the presence of which in RNA and absence in DNA constitutes the only primary structural difference between the two types of nucleic acid. For both of these reasons, if stability of the primary genetic material is a criterion of its evolutionary selection, susceptibility towards metal ions seems much more important than susceptibility towards heat. It is of course possible that evolutionary selection of the structure was in response to pressures other than stability and coincidentally resulted in DNA with high stability to metal ion degradation.

JAMES J. Butzow

GUNTHER L. EICHHORN

Laboratory of Molecular Aging,

Gerontology Research Center, National Institutes of Health, Baltimore City Hospitals, Baltimore, Maryland 21224

\footnotetext{
Received December 20, 1974.

1 Eigner, J., Boedtker, H., and Michaels, G., Biochim. biophys. Acta, 51, 165-168 (1961).

2 Eichhorn, G. L., and Butzow, J. J., Biopolymers, 3, 79-94 (1965).

3 Butzow, J. J., and Eichhorn, G. L., Biopolymers, 3, 95-107 (1965)

4 Eichhorn, G. L., Tarien, E., and Butzow, J. J., Biochemistry, 10, 2014-2019(1971).

5 Butzow, J. J., and Eichhorn, G. L., Biochemistry, 10, $2019-2027$ (1971).

Bamann, E., Trapmann, H., and Fischler, F., Biochem. Z., 326, 89-96 (1954).

7 Shin, Y. A., and Eichhorn, G. L., Biochemistry, 7, 1026-1032 (1968)

8 Felsenfeld, G., and Miles, H. T., A. Rev. Biochem., 36, 407-448 (1967).
9 Shin, Y. A., Heim, J. M., and Eichhorn, G. L., Bioinorg. Chem., 1, 149-163 (1972).

10 Huang, R. C., and Huang, P. C., J. molec. Biol., 39, 365-378 (1969).

12 Eichhorn, G. L., and Clark, P., Proc, natn. Acad. S

13 Fresco, J., and Doty, P., J. Am. chem. Soc., 79, 3928-3929 (1957)
}

\section{Amounts of isoaccepting lysine tRNAs change with the proliferative state of cells}

VARIATIONS in isoaccepting tRNA populations occur in mammalian cells during development, neoplasia, and virus infection, and such changes may reflect the involvement of tRNA in regulatory processes ${ }^{1,2}$, although firm evidence to that effect is not available. Ortwerth and $\mathrm{Liu}^{3}$ have shown that in normal or neoplastic cells an isoaccepting species of lysine tRNA, tRNA ${ }_{4}{ }^{\mathrm{Lys}}$, is present in dividing cells but absent from non-dividing cells. Ortwerth et al. ${ }^{4}$ determined some of the functional properties of $\mathrm{TRNA}_{4}{ }^{\mathrm{Ls}}$ from various tissues and obtained evidence that the species is a real isoacceptor of $\operatorname{tRNA}^{\mathrm{L} y \mathbf{s}}$ rather than an artefact. Normal, proliferating cells that were examined had only relatively small amounts of $\mathrm{tRNA}_{4}{ }^{\mathrm{Ls}}$; however, a larger proportion of the isoacceptor was found in neoplastic cells such as mouse leukaemia and Morris hepatoma cells. It is desirable, therefore, to establish whether the large amount of $\operatorname{tRNA}_{4}{ }^{\mathrm{L} y s}$ is peculiar to the neoplastic state or whether normal cells may also have large amounts of that isoacceptor under some growth conditions. Therefore, we studied isoaccepting lysyl-tRNA profiles from mouse cells in different states of proliferation: adult liver, embryo and growing and quiescent primary cultures of embryonic cells. We found that normal growing cells also have an appreciable amount of $\mathrm{tRNA}_{4}{ }^{\mathrm{L}}$ ss .

Ten-day-old mouse embryos, with heads and extremities removed, were prepared for monolayer tissue culture by dispersing cells with trypsin and seeding in roller bottles in Eagle's $\mathrm{MEM}^{5}$ containing penicillin $\mathrm{G}\left(100 \mathrm{U} \mathrm{ml}^{-1}\right)$, streptomycin $\left(100 \mu \mathrm{g} \mathrm{ml}^{-1}\right)$ and $10 \%$ foetal calf serum. tRNA and aminoacyltRNA ligases were isolated from primary cells, embryo and liver as previously described ${ }^{6}$ and tRNA was purifed further by DEAE-cellulose chromatography?. tRNA was aminoacylated with lysine as before ${ }^{8}$.

In mouse leukaemia cells in suspension culture, $\operatorname{tRNA}_{4}{ }^{\mathbf{l y s}}$ is $47 \%$ of the total tRNA ${ }^{\mathrm{Lys}}$, and this amount decreases to $16 \%$ as cell density increases and proliferation stops ${ }^{3}$. Comparable data on the amount of $\mathrm{tRNA}_{4}{ }^{\mathrm{L} \text { ys }}$ in a uniform population of rapidly dividing normal cells and the effect of increasing cell density were not available. We have compared the Lys-tRNA ${ }^{\text {Lys }}$ profiles of growing and density-inhibited quiescent primary cultures of embryonic cells. The results (Fig. 1a) indicate a much larger amount of $\mathrm{RNA}_{4}{ }^{\mathrm{L} y s}$ in growing cells than in resting cells. Consistent with these results is the finding of an appreciable amount of $\mathrm{TRNA}_{4}{ }^{\mathrm{L} y \mathrm{~s}}$ in embryonic cells which were not in tissue culture (Fig. $1 b$ ). These results also indicate that placing the cells in tissue culture does not in itself lead to an altered $\mathrm{TRNA}^{\mathrm{L} y \mathrm{~s}}$ profile. In contrast to results with proliferating cells, tRNA ${ }_{4}{ }^{\mathrm{L} y s}$ is present only in a very small amount in adult mouse liver (Fig. 1c).

The results are summarised in a quantitative manner in Table 1. tRNA $_{4}{ }^{\mathrm{L} y \mathrm{~s}}$ varies from $3 \%$ in adult mouse liver to $24 \%$ in proliferating monolayer culture. Similar results with cultured murine sarcoma virus-transformed cells (H. J., D. J., and C. H., unpublished) and SV40-transformed cells (J. Katze, personal communication) have been obtained. In toth cases, $\operatorname{tRNA}_{5 \mathrm{a}}{ }^{\mathrm{L} y \mathrm{~s}}$ (ref. 8) seems to be present in addition to $\mathrm{TRNA}_{4}{ }^{\mathrm{Lys}}$ in rapidly proliferating cells and decreases as the cell population becomes

Table 1 Effect of state of growth of cells on chromatographic distribution of isoacceptors of lysine tRNA

\begin{tabular}{|c|c|c|c|c|c|}
\hline \multirow[t]{2}{*}{ Cells } & \multirow[t]{2}{*}{$\begin{array}{l}\text { Growth } \\
\text { state }\end{array}$} & \multicolumn{4}{|c|}{$\begin{array}{c}\text { Distribution of lysine } \\
\text { tRNA isoacceptors }\end{array}$} \\
\hline & & 1 & 2 & 4 & \\
\hline Adult mouse liver & Quiescent & - & 58 & 3 & 38 \\
\hline Primary mouse embryo & Quiescent & 2 & 50 & 9 & 40 \\
\hline Mouse embryo & Growing & 4 & 37 & 15 & 44 \\
\hline Primary mouse embryo & Growing & 2 & 35 & 24 & 38 \\
\hline
\end{tabular}

